\title{
Analysis of the transcriptome of bovine endometrial cells isolated by laser micro- dissection (1): specific signatures of stromal, glandular and luminal epithelial cells
}

Wiruntita Chankeaw ${ }^{1,2}$, Sandra Lignier ${ }^{3}$, Christophe Richard ${ }^{3}$, Theodoros Ntallaris', Mariam Raliou ${ }^{3}$, Yongzhi Guo , Damien Plassard ${ }^{4}$, Claudia Bevilacqua ${ }^{5}$, Olivier Sandra ${ }^{3}$, Göran Andersson ${ }^{6}$, Patrice Humblot ${ }^{1}$ and Gilles Charpigny ${ }^{3,6^{*}}$ (1)

\begin{abstract}
Background: A number of studies have examined mRNA expression profiles of bovine endometrium at estrus and around the peri-implantation period of pregnancy. However, to date, these studies have been performed on the whole endometrium which is a complex tissue. Consequently, the knowledge of cell-specific gene expression, when analysis performed with whole endometrium, is still weak and obviously limits the relevance of the results of gene expression studies. Thus, the aim of this study was to characterize specific transcriptome of the three main cell-types of the bovine endometrium at day-15 of the estrus cycle.

Results: In the RNA-Seq analysis, the number of expressed genes detected over 10 transcripts per million was 6622, 7814 and 8242 for LE, GE and ST respectively. ST expressed exclusively 1236 genes while only 551 transcripts were specific to the GE and 330 specific to LE. For ST, over-represented biological processes included many regulation processes and response to stimulus, cell communication and cell adhesion, extracellular matrix organization as well as developmental process. For GE, cilium organization, cilium movement, protein localization to cilium and microtubule-based process were the only four main biological processes enriched. For LE, over-represented biological processes were enzyme linked receptor protein signaling pathway, cell-substrate adhesion and circulatory system process.

Conclusion: The data show that each endometrial cell-type has a distinct molecular signature and provide a significantly improved overview on the biological process supported by specific cell-types. The most interesting result is that stromal cells express more genes than the two epithelial types and are associated with a greater number of pathways and ontology terms.
\end{abstract}

Keywords: Cow, Endometrium, Cell type-specific, Transcriptome, LCM, RNA-seq

* Correspondence: gilles.charpigny@inrae.fr

${ }^{3}$ Université Paris-Saclay, UVSQ, INRAE, BREED, 78350 Jouy-en-Josas, France

${ }^{6}$ Department of Animal Breeding and Genetics, Molecular Genetics, Swedish

University of Agricultural Sciences, SLU, PO Box 7023, 75007 Uppsala,

Sweden

Full list of author information is available at the end of the article

(c) The Author(s). 2021 Open Access This article is licensed under a Creative Commons Attribution 4.0 International License, which permits use, sharing, adaptation, distribution and reproduction in any medium or format, as long as you give appropriate credit to the original author(s) and the source, provide a link to the Creative Commons licence, and indicate if changes were made. The images or other third party material in this article are included in the article's Creative Commons licence, unless indicated otherwise in a credit line to the material. If material is not included in the article's Creative Commons licence and your intended use is not permitted by statutory regulation or exceeds the permitted use, you will need to obtain permission directly from the copyright holder. To view a copy of this licence, visit http://creativecommons.org/licenses/by/4.0/ The Creative Commons Public Domain Dedication waiver (http://creativecommons.org/publicdomain/zero/1.0/) applies to the data made available in this article, unless otherwise stated in a credit line to the data. 


\section{Background}

In all mammals, successful establishment of pregnancy depends on timely interactions between the developing embryo, the uterine milieu and the endometrium. In species of economic interest such as cattle, a large number of studies have been conducted to establish the basis of the endometrial physiology during the estrus cycle and the first weeks of pregnancy. From a morphological point of view, the bovine endometrium consists of the juxtaposition of large glandular areas with smaller aglandular areas namely intercaruncular and caruncular regions respectively. These two regions are lined by a monostratified luminal epithelium (LE) with convex polygonal cells [1]. In glandular areas, the luminal epithelium penetrates deeply into the underlying tissue and constitutes the branched columnar glandular epithelium (GE). The underlying supporting stroma consists of fibroblastic stromal cells (ST) within a collagen-based connective matrix including vascular and lymphatic vessels as well as infiltrating immune cells. The endometrium is a hormonally regulated tissue and exhibits considerable functional changes during the estrus cycle, which are mainly regulated by progesterone (P4), oestrogens and oxytocin [2]. In bovine, early research using cDNA arrays to analyze changes in gene expression identified a large number of genes expressed differently during the estrus cycle $[3,4]$. Others transcriptional profiling studies have also been performed to determine either the progesterone-regulated genes [5] or the conceptus-induced changes in gene expression [6]. Additionnaly, changes in the global transcriptome of bovine endometrium induced by exposure to blastocysts before and after the conceptus elongation [7] have been investigated to identify novel genes dependent and independent on IFNt [8]. Endometrial transcriptomic studies have been implemented in the context of embryo loss in cattle, which is a major cause of low reproductive efficiency and infertility. In heifers, differences in the endometrial transcriptome have been related to fertility classification $[9,10]$. In almost all studies, transcriptomic profiling was performed on the endometrium as a whole without further refinement. In situ hybridization of transcripts or immunolocalization of proteins were often performed to identify the cell type expressing genes found to be differentially expressed. However, only a small number of transcripts or proteins have been the focus of localization studies. Some studies have attempted to gain a better understanding of the spatiotemporal changes in global gene expression. RNA-sequencing has been used to compare the transcriptome and ability of the ipsilateral and contralateral uterine horns to support preimplantation conceptus survival [11]. Similarly, locoregional differences in the endometrial transcriptome have been demonstrated between the caruncles and intercaruncles in early pregnancy [12] suggesting that the transcriptome should be thoroughly investigated according to the cell types and structures of the endometrium. Previous studies in the mouse indicated cell typespecific differences in transcriptome changes between luminal and glandular epithelium in early pregnancy [13]. Other studies using laser capture microdissection (LCM) to isolate different endometrial cell types have demonstrated their hight potential for understanding the differences in the transcriptional events occurring during the estrus cycle and early pregnancy in ovine [14] and porcine endometrium [15]. To our knowledge, no equivalent study has been performed on the bovine endometrium. The aim of the present study was to characterize the transcriptome using RNA-sequencing in the three endometrial cell types (LE, GE and ST) isolated by LCM at day-15 of the estrus cycle. Since previous in vivo studies showed the effects of metabolic imbalance on endometrial gene expression during the early postpartum period [16], the specific impacts of post-partum negative energy balance on the three endometrial cell-types were also investigated and results reported in a companion paper (under review [17]).

\section{Results}

All cows were cyclic (one full cycle or more) before initiation of the synchronization treatment. Commencement of luteal activity determined as day of first progesterone value above threshold of $3 \mathrm{ng} / \mathrm{ml}$ was $22.8 \pm 10.3$ days; mean \pm SD). Milk progesterone concentrations during the days before biopsy sampling are shown in the supplementary figure-S1. All cows presented high progesterone concentrations (mean $\pm \mathrm{SE} ; 9.88 \pm 2.12 \mathrm{ng} / \mathrm{mL}$ ) and were in the luteal phase at time of endometrial biopsy. Depending on cell type, as many as 30 slides of endometrial sections per animal biopsies had to be processed using LCM to obtain the amount of RNA required for RNA sequencing (Table S1). RNA integrity was preserved during the isolation process and ranged from 7.23 to 7.75 . Figure 1 evidences the cell capture for the GE, LE and ST cells. The absence of contamination of samples by infiltrating immune cells was verified from the screening for immune cell-specific markers in the lists of genes corresponding to each cell type from the RNAseq analysis. None of these specific markers from immune cells were detected at levels such as they could possibly interfere with the expression profiles of endometrial cells (Table S2).

\section{RNA-sequencing of cell type-specific samples collected by LCM}

The sequencing depth of RNA-seq libraries was in the range of 60 to 100 million reads per sample for each endometrial cell type. A total of 22,915 transcripts with a unique Identifier were found. Salmon's method 

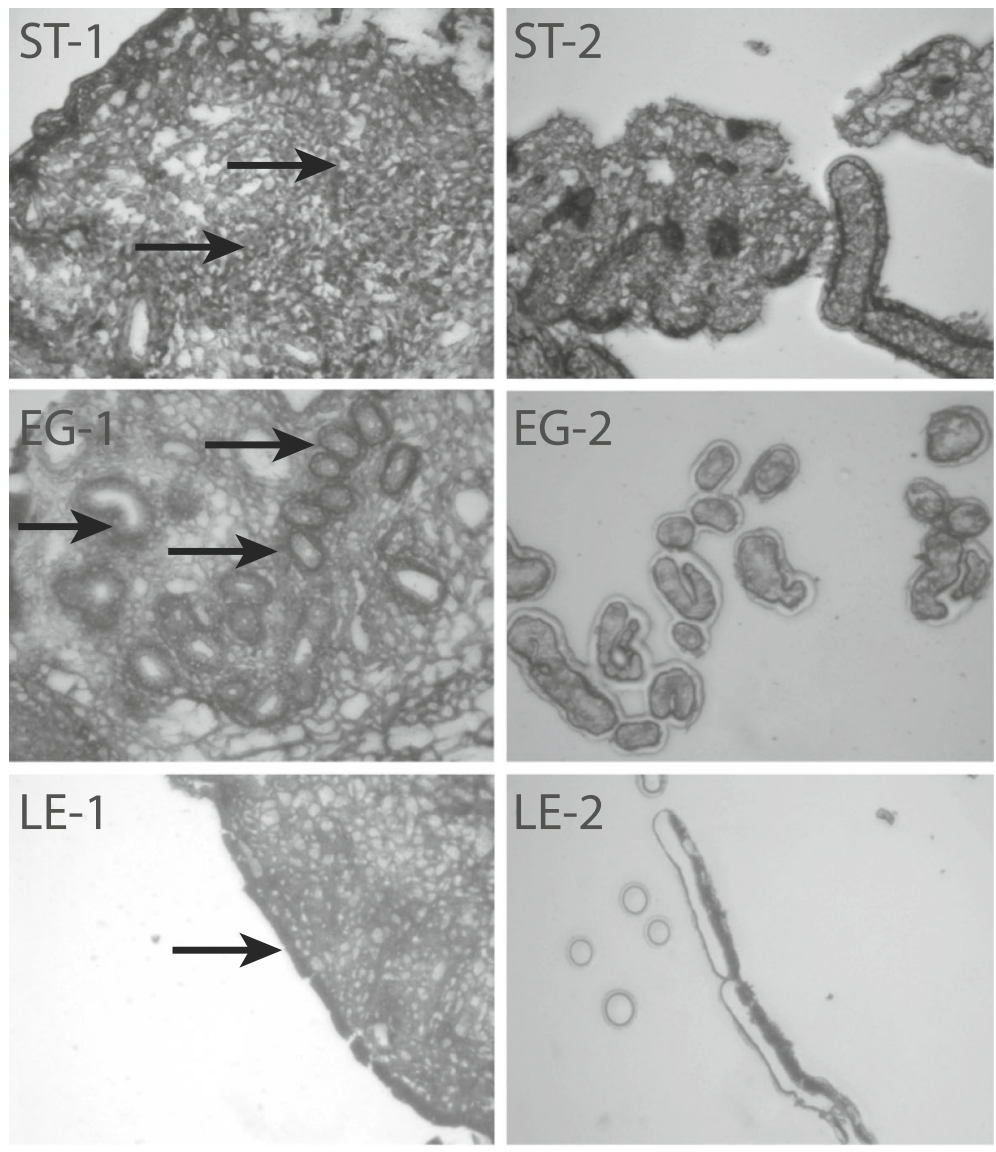

Fig. 1 Isolation of the three bovine endometrial cell types by LCM: stromal cells (ST), glandular epithelial cells (GE) and luminal epithelial cells (LE), before [(1): left column and arrows)] and after [(2): right column] capture by LCM. (400x magnification)

provides both read counts and TPM (transcripts per million), and the latter expression is more appropriate when comparing relative abundance between different cell types or tissues [18]. Before comparing the differences in gene expression between the endometrial cell types, transcripts whose average value, computed from biological replicates, were less than 10 TPM were regarded as biological background noise, partly independent of transcription regulation and discarded. The number of expressed genes detected (higher than 10 TPM) was 6622, 7814 and 8242 for luminal epithelial cells (LE), glandular epithelium (GE) and stromal cells (ST), respectively (Fig. 2A). In the RNA-Seq analysis, the highest number of detectable expressed genes (8242) in the LCM datasets was obtained for ST and the lowest number of detectable genes (6622) was observed for LE. As displayed on the Venn diagram (Fig. 2A), 5672 genes were expressed by all three cell types. A total of 1236 genes were expressed exclusively by ST cells, which represents $15 \%$ of all genes expressed by this type of cell, while only 551 (7\% of all genes expressed) transcripts were specific to the GE cells and 330 (5\%) transcripts specific to LE cell. The lists of genes specifically expressed by each cell type are provided in additional file (TableS3_LE_GE_ST.xlsx). An overview of the GO terms associated to genes specifically expressed by each cellular type is visualized in Fig. 3. The list of 5672 genes expressed in common between the three cell types was used as a reference list for PANTHER overrepresentation tests. Over and under-represented GO terms for biological process were visualized using REVIGO algorithm to reduce term redundancy (corresponding tables of GO terms are provided in additional file (TableS4 GO-REVIGO.xlsx). Respectively 97, 14 and 13 clusters of GO terms were over-represented in ST, GE and LE cells whereas 45,11 and 8 were under-represented. $\mathrm{Nu}$ merous metabolic processes were under-represented in the three lists of genes specifically expressed by each cell type which means that most of the genes involved in metabolism are shared ones. For ST, over-represented biological processes included many regulation processes and response to stimulus, cell communication and cell adhesion, extracellular matrix organization as well as developmental process and wound healing. For GE, cilium 


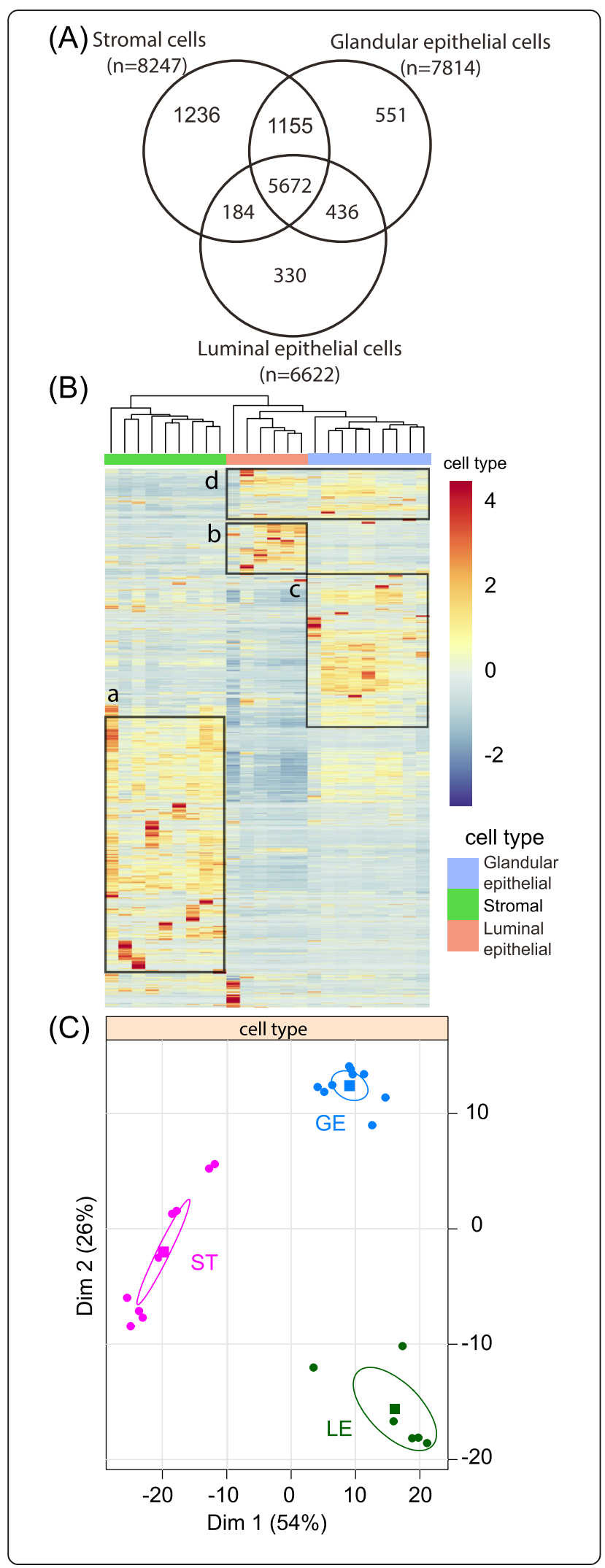

Fig. 2 Transcriptomic analysis of endometrial cell types. (A) Venn diagram from genes expressed more than 10 TPM in specific endometrial cells (LE, luminal epithelial cells; GE, glandular epithelial cells; ST, stromal cells) (numbers of identified genes are indicated). (B) Heat map of genes expressed by ST, GE and LE cells and clustering of the three cellular types (the colors show the relative level of expression. Boxes highlight the more expressed genes for each cell type [(a): stromal cells; (d): luminal epithelial cell type; (c): glandular epithelial cells: (d): epithelial cell type]. (C) Principal component analysis for clustering expressed genes of the three endometrial cell types. Confidence ellipses around the barycenter of each cell type are shown

organization, cilium movement, protein localization to cilium and microtubule-based process were the only four main biological processes enriched. For LE, overrepresented biological processes were enzyme linked receptor protein signaling pathway, cell-substrate adhesion, circulatory system process and activation of adenylate cyclase activity.

Heatmap (Fig. 2B) illustrates that the hierarchical clustering obtained from gene expression unambiguously regroups samples of each cell-type. The most expressed genes for each cell type are highlighted and framed by boxes (Fig. 2B). The corresponding statistical analyses revealed that 8070 genes were differentially expressed (adjusted $p$ value $<0.05)$ between GE and LE cells (3921 genes greater expressed in GE vs. 4149 in LE). The expression of 10,258 genes differs between ST and LE (5319 genes more expressed in ST vs. 4939 more expressed in LE). The level of expression of 9541 genes differs between GE and ST (4538 genes more expressed in GE vs. 5003 in ST).

The principal component analysis confirms the clear separation of the samples from the three cell types (Fig. $2 \mathrm{C})$. The first two dimensions explain $80 \%$ of the variability. The first dimension distinguishes epithelial cells from ST whereas the variation associated to the second dimension relates to differences of expression between GE and LE cells. Supplementary table (Table_S5_ PCA.xlsx; sheets 1 and 2 for the first dimension, sheets 3 and 4 for the second dimension) show the most characteristic genes according to each dimension (at $p<0.01$ ); 124 genes are associated with ST while 217 are associated with the two groups of epithelial cells. Looking at dimension 2, 113 genes are related to GE while 83 genes are attached to LE.

Genes negatively correlated to dimension-1 correspond to genes over-expressed in ST (Table_S5_ PCA.xlsx; sheet 1). Among them, there is a significant over-representation of genes that are involved in extracellular matrix organization (R-BTA-1474244), in integrin signaling pathway (P00034) and in cadherin signaling pathway (P00012) (Table 1). 


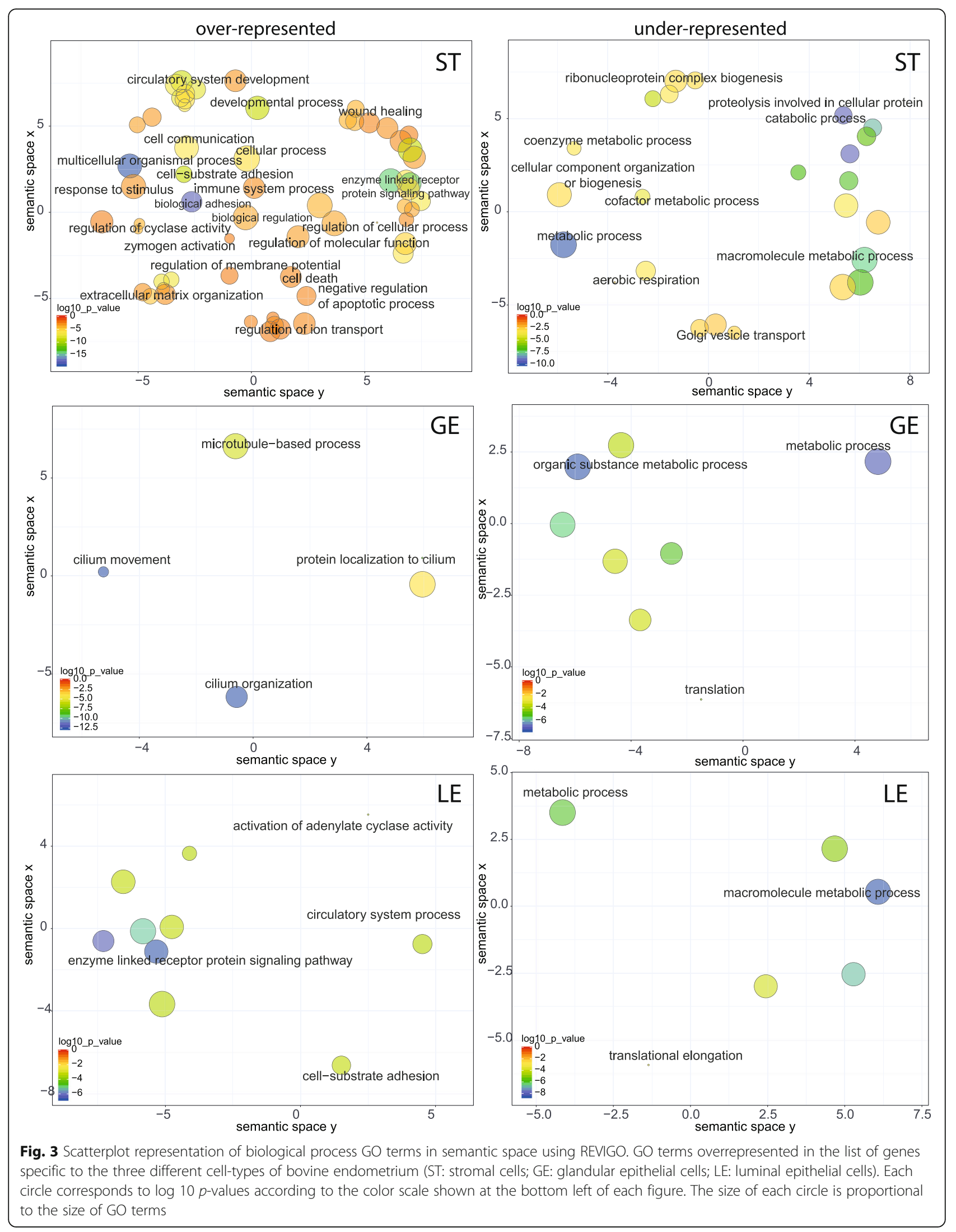


Table 1 Enrichment analysis using Statistical Overrepresentation Test (PANTHER 14.1) on genes negatively correlated to dimension-1 of PCA and associated to endometrial stroma cells (ST); GO terms are provided following PANTHER classification

\begin{tabular}{|c|c|c|c|}
\hline Panther Classification & $\begin{array}{l}\text { fold } \\
\text { Enrichment }\end{array}$ & FDR & genes \\
\hline \multicolumn{4}{|l|}{ PANTHER Pathways } \\
\hline Cytoskeletal regulation by Rho GTPase (P00016) & 9.84 & $\begin{array}{l}1.09 \mathrm{E}- \\
02\end{array}$ & ACTA2, MYH11, ACTG2, MYLK, TUBB6 \\
\hline Integrin signaling pathway (P00034) & 8.58 & $\begin{array}{l}2.62 \mathrm{E}- \\
04\end{array}$ & $\begin{array}{l}\text { COL1A2, COL6A3, COL3A1, ACTA2, ARHGAP10, ACTG2, COL1A1, RND1, } \\
\text { RND3 }\end{array}$ \\
\hline Cadherin signaling pathway (P00012) & 7.27 & $\begin{array}{l}3.12 \mathrm{E}- \\
02\end{array}$ & ACTA2, CDH11, CDH13, ACTG2, PCDH9 \\
\hline \multicolumn{4}{|l|}{ PANTHER GO-Slim Biological Process } \\
\hline circulatory system development (GO:0072359) & 11.56 & $\begin{array}{l}3.90 \mathrm{E}- \\
02\end{array}$ & PDLIM3, SGCG, TNMD, MYLK, THBS1, APOLD1 \\
\hline \multicolumn{4}{|l|}{ Reactome pathways } \\
\hline Smooth Muscle Contraction (R-BTA-445355) & 36.62 & $\begin{array}{l}6.19 \mathrm{E}- \\
02\end{array}$ & ACTA2, MYH11, TPM2 \\
\hline $\begin{array}{l}\text { Formation of Fibrin Clot (Clotting Cascade) (R- } \\
\text { BTA-140877) }\end{array}$ & 36.62 & $\begin{array}{l}4.64 \mathrm{E}- \\
02\end{array}$ & SERPINE2, SERPING1, F10 \\
\hline ECM proteoglycans (R-BTA-3000178) & 33.29 & $\begin{array}{l}1.74 \mathrm{E}- \\
02\end{array}$ & COL6A3, TNXB, COLIA1, DCN \\
\hline Extracellular matrix organization (R-BTA-1474244) & 9.36 & $\begin{array}{l}1.08 \mathrm{E}- \\
02\end{array}$ & $\begin{array}{l}\text { COL5A2, COL1A1, ADAMTS1, SMOC2, COL1A2, ECM2, MMP19, SULF1, } \\
\text { COL3A1, MFAP4 }\end{array}$ \\
\hline
\end{tabular}

Other genes associated with smooth muscle contraction (R-BTA-445355), cytoskeletal regulation by Rho GTPase (P00016) and with formation of fibrin clot (RBTA-140877) are also more expressed in ST.

Genes positively correlated to dimension-1 are overrepresented in both GE and LE Table_S5_PCA.xlsx; sheet 2). Table 2 shows enrichment of genes coding for proteins involved in epithelial cell differentiation (GO: 0030855), epithelium development (GO:0060429) and in cell adhesion (GO:0007155). This first group of genes encodes proteins for cell junction (PC00070) and tight junction (PC00214. A second group of genes associated and over-represented in the epithelial cells is encoding proteins for secondary carrier transporter (PC00258) and transporter (PC00227). By looking in more details (Table_S5_PCA.xlsx; sheet 2), epithelial cells are enriched in genes involved in cellular response to stimulus (GO: 0051715) and signal transduction (GO: 0007165) (RHPN2, DYNCI1, RAB25, F2RL1, ITGB6, LPAR3, KSR2 and ERBB3). Genes encoding proteins for catalytic activity (GO:0003824) such as enzymes of metabolism GPT2, PLA2G4A, AKR1B and IDH1 are also over-expressed in these cells, as well as genes associated to EGF signaling pathway (P00018) and cell proliferation (MAPK13, PEBP4, ERBB3, CCNA1 and RAB25).

When addressing the genes associated to GE cells (Table_S5_PCA.xlsx; sheet 3) and according to Panther Molecular Function classification, 20 genes are related to catalytic activity (GO:0003824), 12 to binding (GO: 0005488) and 8 to transporter activity (GO:0005215).
According to Panther Biological Process classification, 20 are related to cellular process (GO:0009987), 16 to metabolic process (GO:0008152), 12 to biological regulation (GO:0065007), 9 to immune system process (GO: 0002376) and 8 to response to stimulus (GO:0050896). Table 3 summarizes the over-representation of genes associated to GE cells. These genes encode proteins associated to related GO terms: microtubule (GO:0005874), intraciliary transport particle (GO:0030990), ciliary plasm (GO:0097014) and plasma membrane bounded cell projection cytoplasm (GO:0032838). These proteins are involved in axonemal dynein complex assembly (GO: 0070286) and cilium movement (GO:0003341).

GE cells are also characterized by a significant number of genes coding proteins which are embedded in the cell membrane (integral component of membrane GO:0016021).

LE cells are mainly characterized by genes coding for enzymes metabolite interconversion enzyme, PC00262) and for transporter (PC00227) (Table_S5_PCA.xlsx; sheet 4). Panther overrepresentation test (Table 4) identifies enrichment for two groups of genes encoding transporters (secondary carrier transporter, PC00258) and proteases inhibitors (protease inhibitor, PC00191). Moreover, according to GO cellular component classification, there are also a large number of genes products that are known to be secreted from cells into the extracellular space (extracellular space, GO:0005615). LE expressed PTGS2 and OXTR which are involved in oxytocin-stimulated prostaglandin release. Four LE genes GPDL1, FST, NPPC and NR4A1 pointed out the 
Table 2 Enrichment analysis using Statistical Overrepresentation Test (PANTHER 14.1) on genes positively correlated to dimension-1 of PCA and associated to endometrial luminal and glandular epithelial cells (LE, GE); GO terms are provided following PANTHER classification

\begin{tabular}{|c|c|c|c|}
\hline Panther Classification & $\begin{array}{l}\text { fold } \\
\text { Enrichment }\end{array}$ & FDR & genes \\
\hline \multicolumn{4}{|c|}{ PANTHER GO biological process complete } \\
\hline $\begin{array}{l}\text { epithelial cell differentiation (GO: } \\
\text { 0030855) }\end{array}$ & 5.59 & 1.39E-04 & $\begin{array}{l}\text { CLDN3, SYNE4, LRP2, F2RL1,DLX6, ELF3, SPINT1, PHGDH, OVOL1, TACSTD2, ST14, EHF, } \\
\text { MSX1, EPCAM, ST14, KDF1, IRF6, TJP3, HNF1B, SLC44A4, RAB25, DSP, MCOLN3 }\end{array}$ \\
\hline $\begin{array}{l}\text { epithelium development (GO: } \\
\text { 0060429) }\end{array}$ & 3.87 & 2.05E-04 & \\
\hline cell adhesion (GO:0007155) & 3.19 & $5.76 \mathrm{E}-02$ & $\begin{array}{l}\text { CLDN3, AZGP1, DSG2, PERP, FOLR1, FOLR1, SPAG6, EPCAM, CLDN7, CLDN4, CXADR, TJP3, } \\
\text { IGSF5, CDH1, ITGB6, DSP }\end{array}$ \\
\hline \multicolumn{4}{|l|}{ PANTHER Protein Class } \\
\hline $\begin{array}{l}\text { tight junction (PC00214), cell } \\
\text { junction protein (PC00070) }\end{array}$ & 15.64 & $1.96 \mathrm{E}-03$ & CLDN3, CLDN8, CLDN7, CLDN4, TJP3 \\
\hline $\begin{array}{l}\text { secondary carrier transporter } \\
\text { (PC00258), transporter (PC00227) }\end{array}$ & 8.55 & $2.11 \mathrm{E}-06$ & $\begin{array}{l}\text { SLC13A5, SLC44A3, SLC5A11, SLC5A11, SLC39A2, SLC27A6, SLC7A4, SLC5A1, SLC27A2, } \\
\text { SLC34A2, SLC44A4, SLC5A8 }\end{array}$ \\
\hline \multicolumn{4}{|l|}{ PANTHER Pathways } \\
\hline $\begin{array}{l}\text { Serine glycine biosynthesis } \\
\text { (P02776) }\end{array}$ & 44.23 & 1.65E-02 & PSAT1, PHGDH \\
\hline
\end{tabular}

gonadotropin-releasing hormone receptor pathway (P06664) in the endometrial luminal cells.

\section{Discussion}

\section{Transcriptome of the three endometrial cell types}

Our results fully confirm that stromal cells, glandular and luminal epithelial cells reveal specific molecular signatures as documented before in studies using LCM in human [19], sheep [14] and horse [20]. As the endometrial biopsies were all collected in the luteal phase of a synchronized estrous cycle, the conclusions of this study are relevant for the transcriptional events which are related to the endometrium exposed to high progesterone levels. Regulation of gene expression of the three endometrial cell types, under elevated estrogen concentrations during the follicular phase of the cycle would deserve similar studies. Our results based on biopsies collected in the luteal phase, have shown that a higher number of genes with a strong constitutive expression in stromal cells when compared with epithelial cells (either

Table 3 Enrichment analysis using Statistical Overrepresentation Test (PANTHER 14.1) on genes positively correlated to dimension-2 of PCA and associated to endometrial glandular cells (GE); GO terms are provided following PANTHER classification

\begin{tabular}{|c|c|c|c|}
\hline Panther Classification & $\begin{array}{l}\text { fold } \\
\text { Enrichment }\end{array}$ & FDR & genes \\
\hline \multicolumn{4}{|l|}{ PANTHER GO-Slim Biological Process } \\
\hline $\begin{array}{l}\text { axonemal dynein complex assembly } \\
\text { (GO:0070286) }\end{array}$ & 56.29 & $3.94 \mathrm{E}-02$ & CCDC65, ZBBX, DNAI1, DRC1, DRC3, DAW1, CFAP45, DNAH5, DNAH9 \\
\hline cilium movement (GO:0003341) & 26.63 & $4.93 \mathrm{E}-04$ & \\
\hline \multicolumn{4}{|l|}{ PANTHER GO-Slim Cellular Component } \\
\hline axoneme (GO:0005930) & 15.58 & $2.16 \mathrm{E}-02$ & CCDC65, SPAG17, DNAI1, DRC1, DNAH9 \\
\hline ciliary plasm (GO:0097014) & 15.01 & $1.97 \mathrm{E}-02$ & \\
\hline $\begin{array}{l}\text { plasma membrane bounded cell } \\
\text { projection cytoplasm (GO:0032838) }\end{array}$ & 13.76 & $2.25 \mathrm{E}-02$ & \\
\hline $\begin{array}{l}\text { intraciliary transport particle (GO: } \\
\text { 0030990) }\end{array}$ & 7.94 & $3.54 \mathrm{E}-02$ & CCDC65, FAM183A, SPAG17, ZBBX, DNAl1, DRC1, DNAH5, DNAH9 \\
\hline microtubule (GO:0005874) & 7.64 & $2.88 \mathrm{E}-02$ & \\
\hline $\begin{array}{l}\text { integral component of membrane } \\
\text { (GO:0016021) }\end{array}$ & 3.40 & 8.29E-2 & $\begin{array}{l}\text { ADAMDEC1, LRP2, MGAT4C, CLDN10, CLDN8, CYP2D14, GJB5, LRAT, LDLRAD1, } \\
\text { MCOLN2, MCOLN3, NXPE2, NRCAM, SDR16C5, SLC13A5, SLC15A2, SLC27A6, SLC36A2, } \\
\text { SLC38A11, SUSD2, SV2B, TMPRSS2, TMEM144 }\end{array}$ \\
\hline extracellular region (GO:0005576) & 2.27 & $1.79 \mathrm{E}-02$ & $\begin{array}{l}\text { BPIFB1, SERPINE2, PLA2G10, MPTX, MGP, SPAG17, CPN1, PIP, SUSD2, S100B, CPN1, } \\
\text { TDGF1, WIF1 } \\
\text { DNAI1, BPIFB1, AGT, MYOC, PIP, MYOC, IHH }\end{array}$ \\
\hline
\end{tabular}


Table 4 Enrichment analysis using Statistical Overrepresentation Test (PANTHER 14.1) on genes negatively correlated to dimension-2 of PCA and associated to endometrial luminal cells (LE); GO terms are provided following PANTHER classification

\begin{tabular}{|c|c|c|c|}
\hline Panther Classification & $\begin{array}{l}\text { fold } \\
\text { Enrichment }\end{array}$ & FDR & genes \\
\hline \multicolumn{4}{|l|}{ PANTHER Protein Class } \\
\hline $\begin{array}{l}\text { secondary carrier } \\
\text { transporter (PC00258) }\end{array}$ & 11.91 & $\begin{array}{l}5.28 \mathrm{E}- \\
04\end{array}$ & SLC4A11, SLC5A11, SLC39A2, GDA, SLC5A8, cationic amino acid transporter 3-like \\
\hline $\begin{array}{l}\text { protease inhibitor } \\
\text { (PC00191) }\end{array}$ & 11 & $\begin{array}{l}4.38 \mathrm{E}- \\
04\end{array}$ & A2M, ITIH4, FST, IGFBP2, IGFBP1, AHSG, SLPI \\
\hline \multicolumn{4}{|c|}{ GO cellular component complete } \\
\hline $\begin{array}{l}\text { extracellular space (GO: } \\
\text { 0005615) }\end{array}$ & 3.55 & $\begin{array}{l}5.38 \mathrm{E}- \\
04\end{array}$ & $\begin{array}{l}\text { GPLD1, A2M, ITIH4, CHGA, FST, SFRP4, ULBP21, FAM3B, LCAT, CFB, TINAGL1, IGFBP2, FGF9, TNC, } \\
\text { IGFBP1, TACSTD2, SCG3, NPPC, LAMB3, SMPDL3B, GPRC5A, AHSG, SLPI, PRSS22, FGFBP1 }\end{array}$ \\
\hline
\end{tabular}

glandular or luminal) are different from the expression pattern observed at the beginning of pregnancy [20]. This may result from differences between species but could also reveal the changes induced by the conceptus on the endometrial transcriptome previously reported from full tissue [16, 21] and epithelial cells [14].

Using a cut-off of 10 TPM, different numbers of genes were expressed in the three endometrial cell types. ST expressed 5 and $25 \%$ more genes than GE and LE, respectively. However, as reported before from a large variety of tissues [22], and the three laser-dissected cell types of porcine endometrium [15], our results confirm that a high number of genes are expressed in common in different endometrial cell types. In the present study, 70 to $85 \%$ of genes were expressed in all cells suggesting either "house-keeping" functions or genes encoding proteins with functions common to the endometrium while lower proportions (5, 7 and 15\% for LE, GE and ST, respectively) were restricted to each cell type indicating that they code for proteins supporting the functional specialized signature of each cell type. When compared to porcine endometrium [15], the number of genes showing cell-specific expression is in the same order of magnitude for GE and LE, but appears different for ST cells where this number is ten times higher. These differences in specific expression between cell types, especially the large number of functions enriched in ST are well reflected by the REVIGO analysis.

Regardless of the cut off chosen and related limitations, the above studies illustrated huge differences in gene expression patterns between cell types corresponding to specialized functions. This confirms that separating cell types is more appropriate and possibly less biased to decipher the impacts of any factor on a given tissue than former approaches based on full tissue. The clear clustering obtained when analysing the full transcriptome, indicates that luminal and glandular epithelial cells are more close to each other and differ from stromal cells. These similarities may reflect common functional properties and/or may be related to the common epithelial nature of these cells.
The RNaseq analysis generated 20,782 Ensembl stable identifiers. Among these mRNAs, 8070 (38\%), 9541 (45\%) and 10,258 (49\%) were found differentially expressed between GE and LE, ST and LE, GE and ST respectively. As mentioned above, there are fewer differential expressed genes between GE and LE than between ST and the two epithelial cell types. As a common trend, The REVIGO analysis showed that genes encoding proteins related to metabolism were under-represented among genes specifically expressed by each cell type.

The stroma is dense and composed mainly of fibroblasts which produce the extracellular matrix. It contains also blood vessels which may be the source of endothelial cells in samples. In addition, depending on the physiological and health status of the cows, the stroma contains a variable number of resident and migrating immune cells such as macrophages, lymphocytes and eosinophils. However, Laser capture microdissection, by carefully selecting the cells to be picken, ensures that the sample is not contaminated by blood vessels. The presence of infiltrating immune cells may be a source of heterogeneity as these although visible, may be more difficult to eliminate from the stroma samples. The former selection of cows with low density of immune cells from cytology probably contributed to limit this possible source of contamination and we could not find tracks of specific RNA signatures of immune cells in our samples. Other sources of heterogeneity of stroma samples may exist which are more difficult to control. Most particularly, the stromal cells constituting the endometrial caruncle should have a different expression phenotype from that of the basal layer stromal cells which is located near the myometrium. Also, it has been suggested that the mammalian endometrium may contain adult stem cells of different types [23] which would be source of heterogeneity of the stromal cell population. The presence of these cells could confer additional RNA signatures and this could partly explain why more genes were differentially expressed in ST samples than in GE and LE samples. 
An exhaustive analysis of the differentially expressed genes is beyond the scope of the discussion of this article and detailed information is provided in the supplementary tables. Below we have focused on highlighting the main genes that strongly contribute to the separation between the 3 cell types observed in PCA and for which expression may lead to the phenotype of each cell type. Using the official gene symbol approved by the HUGO Gene Nomenclature Committe, we performed a search of previously published articles limited to genes contributing to the dimensions of PCA. Search for terms [(endometrium or uterus) AND (bos or ovis or cow or bovine or ovine or sheep or ewe)], was combined in the PubMed Advanced Search Builder. Results indicate that only 10,28 and $31 \%$ of the genes identified in the present study had been previously described in the uterus of ruminant species for respectively GE, LE and ST cells.

The genes associated with GE and LE, which distinguish the two types of epithelial cells from stromal cells, are all related to GO terms typical of epithelia (GO: 0030855, epithelial cell differentiation; GO: 0060429, epithelium development; PC00214: tight junction; PC00070: cell junction protein). $C D H 1$ was found expressed in $\mathrm{GE}$ and LE as previously described in the ovine uterus [24] whereas $C D H 16$ and $C D H 17$ was mentioned to be localized only in LE. CDH1 is involved in organization of epithelium in mouse and its ablation causes the absence of endometrial glands [25]. Occludin (OCLN) which is an important protein for tight junction assembly that preserves the epithelial barrier function was expressed in both GE and LE. Temporal and spatial modifications in $O C L N$ expression was reported to be related to cyclic and pregnant ewes [24]. LE expressed two additional cadherins, $C D H 16$ and $C D H 17$, which were never reported in uterus of any species. $\mathrm{CDH} 16$ and $\mathrm{CDH} 17$ are cadherins containing 7 cadherin domains and extensively shown to be expressed in the intestinal epithelial cells and kidney respectively [26]. On the contrary, ST cells express here two particular cadherins, CDH11 and CDH13 which have not, to our knowledge, been found in the uterus. CDH11 is a type II classical cadherin lacking cell adhesion recognition sequence and has been reported to be involved in the process of epithelial to mesenchymal transition [27]. $\mathrm{CDH} 13$ is an atypical member of the cadherin family, without transmembrane domain which has been associated with poorer prognosis in various cancers [28]. We report here also the expression of six different claudins (CLDNs) which label the three cell types differently. CLDN3 are CLDN7 are associated with GE and LE whereas CLDN8 and CLDN10 are expressed only by GE and CLDN4 only by LE. CLDN5 was associated here with ST but was previously detected in epithelial tissue in mouse uterus [29].
Consistently to what was reported in ewes [24] CLDN3 and CLDN4 were more expressed in LE and GE than in ST. However, contrary to the previous study [24], we were unable to detect $C L D N 1$ and $C L D N 2$ as junctional proteins differentiating cell types. This could be due to the fact that CLDN1, reported only at very low levels in LE and GE when progesterone reached its highest concentration [24], could not be detected in our experiment since the animals were biopsied on day 15 of the cycle. Alternatively, this may relate to differences between species. We identified a homeobox gene associated to GE and LE, DLX6, which has a similar pattern of expression in glandular and lining epithelial cells of mouse and human endometrium [30]. EHF, associated to GE and LE is an epithelium-specific transcription factor previously described in airway, intestinal and skin epithelia but never mentioned in the endometrium although it has been reported in uterine carcinosarcoma [31].

About 20 genes of membrane-bound solute carrier (SLC) transporter contribute significantly to the discrimination of the three cell types. Only one is specific to ST (SLC2A3), while all the others are associated to epithelial cells and reveal a significant enrichment of this class of proteins (PC00258). SLC27A2, SLC34A2, SLC44A3, SLC44A4, SLC7A4, SLC22A16, SLC1A1 and SLC23A1 are expressed by both GE and LE. Moreover additional solute carriers are specific either to GE or to LE. SLC13A5, SLC15A2, SLC27A6, SLC28A3, SLC36A2 and $S L C 38 A 11$ are associated with GE whereas $S L C 4 A 11$ and SLC25A16 are associated with LE. Using a gene candidate approach, Bazer's group described the regulated expression of 14 genes coding for SLC in the ovine endometrium [32-34]. The present exploratory study recognises only three of the SLC described in the above references. Our results for members of the SLC2 and SLC5 families, which are involved in sugar uptake, are partly in agreement with those previously published. We observed that SLC5A1 was expressed in both LE and GE as in cow [35] and in ewe [34]. However SLC5A11 was reported as more abundant in GE than in LE [34] whereas we found this gene specifically expressed in LE. Moreover we identify SLC2A3 in ST whereas the type 4 of $S L C 2 A$ was detected in these cells [35]. One may question the differences observed between the candidate approaches and our exploratory study. We focused on investigating the genes that differentiate cell types. By exploring the gene lists (TableS3_LE_GE_ST.xlsx) from RNAseq analysis, more than 100 SLCs are expressed in the bovine endometrium when using the cut-off of 10 TPM. When considering only those SLC markedly expressed (over 100 TPM), epithelial cells looks more enriched in SLC than stromal cells (14, 23 and 8 SLCs for GE, LE and ST respectively). This could be consistent with the fact that enrichment of receptors within the 
epithelium is essential for epithelial functions, particularly to regulate the composition of the luminal fluid [36].

GE are highly enriched for a large group of genes encoding for proteins related to cilium movement such as dyneins (GO:0003341). The dynein associated proteins are known to participate in numerous cellular functions involving microtubules bases movement [37]. Inside the cell, dynein powers the transport of membranes vesicles such as endosomes, lysosome, lipid droplets and vesicles. Predominantly expressed in ciliated cells, dynein drive the sliding of adjacent microtubules in the motile axonemes and provokes deformations resulting in cilia oscillations [37, 38]. For long, ciliated cells have been recognized as organelles involved in motility. In the bovine species, oviduct ovum transport is likely to result from ciliary beat [39]. Such a function remains difficult to warrant for the uterine glands. Motile cilia promote also fluid movement at the apical surface of the epithelium [38]. It could be speculated that the above role is certainly effective in the uterine glands as these are responsible for the secretion of the main part of the histotrophic molecules. However since the glandular epithelium of ruminant species is composed of fewer ciliated cells than non-ciliated cells [1, 40,41], additional hypotheses are needed to explain the enrichment of GE with proteins of axonemal dynein complex assembly. On the contrary to mice where $I H H$ was located in LE [42], we found this gene strongly associated with GE. In mice $I h h$ is suspected to be involved in uterine gland morphogenesis and epithelial cell proliferation. Since hedgehog signaling is known to be tightly coupled to the maintenance and function of primary cilia in various mammalian cell types [37], we suggest that both $I H H$ and genes of the dynein complexes are involved in the maintenance of glandular epithelial cell functions in bovine.

The endometrium contains proteinase inhibitors and related molecules whose roles are not fully understood $[43,44]$. Our results show that these proteinase inhibitors are mainly related to epithelial cells. Molecules such as SERPINA14, which is a major progesterone-induced protein secreted in the ruminant uterine fluid, is thought to act as an immune-modulator during pregnancy [43]. In our study, SERPINA14 is associated with both GE and LE whereas the protein was previously reported to be preferentially located in GE [45]. SERPINE2, described as an endometrium plasminogen inhibitor in humans [46] and SERPIN11 were not yet described in the ruminant uterus. ST also expressed two distinct serineproteinase inhibitors, SERPING1 and SERPINE1. AHSG, a plasma protein, produced primarily by the liver was previously reported in bovine endometrium [47]. In the current work, AHSG expression was associated with LE. AHSG is known to play a role in controlling the localisation and breakdown of IGFBP proteins within tissues.
IGFBPs, which are involved in the bio-avaibility of IGFs, were intensively studied in the bovine uterus [48-50]. We found IGFBP1and IGFBP2 as main markers of LE as described before $[49,51]$, whereas others have reported a widespread distribution in the endometrium [47]. Besides these well-known markers, LE expressed other genes, for which little is known in the bovine, encoding proteinase inhibitors involved either in the immune system, such as SLPI and $A 2 M[52,53]$, in the regulation of uterine glycocalyx (ITIH4) [54] or in the activin pathway controlling the development of conceptus (FST) [55].

Three ectonucleotide pyrophosphatases/phosphodiesterases; ENPP3-5 were associated with both GE and LE. Surprisingly, ENPP2 has not been described so far as a marker of epithelial cells although this enzyme has been shown responsible for the uterine synthesis of lysophosphatidic acid in ruminants $[56,57]$. We identified LPAR3 as an epithelial gene as previously reported [58] while genes coding for proteins involved in oxytocininduced prostaglandins PTGS2 and OXTR were only associated with LE. Our results are in agreement with previous studies showing that OXTR was exclusively observed in luminal epithelium during luteal phase in cycling cow [59].

By contrast, a very large number of functions including but not limited to, cell structure, angiogenesis, extra cellular matrix and immunity are enriched in ST whereas a lack of strong expression of these genes is observed in GE and LE. As awaited, among the genes most discriminating stromal cells, those involved in the production of extracellular matrix and collagen are highly represented. COL1A2, COL3A1, COL7A1 and COL3A3 encode proteins involved in dynamic remodeling of endometrial extracellular matrix and regulate embryo receptivity in cattle [60]. In addition, we identified here genes associated with extracellular matrix organization, which have not been previously described in the bovine endometrium. These includes $L O X L 2$, responsible for the crosslinking of collagen and elastin [61], ECM2 involved in the regulation of cell proliferation and differentiation [62] and CRISPLD1 known to regulate extracellular matrix and branching morphogenesis [63]. These genes encode proteins that may have an important role in the formation of glands and vasculature of the bovine endometrium as well as WT1, already known to be preferentially expressed in stromal endometrial cells [64, 65].

We identify here also original genes related to stromal cell differentiation and cell migration such as $C D H 11$, PRELP, THY1 (the latter encoding a stem cell marker) [66], GJA1 [67], OSR2 [68], P4HA3. PRLEP gene expression has been reported to be regulated by the embryo in the bovine oviduct [69]. Contrary to the porcine endometrium where its expression was reported to be located in epithelial cells [[70], NTRK2 was mainly expressed 
here in stromal cells. The expression of the NTRK2 gene, which encodes the receptor of brain derived neurotrophic factor, is conserved in mammalian uterus but its signaling function is not yet understood in the female reproductive system [71]. Genes known to be key regulators of uterine receptivity in different species such as, HOXA10 and HOXA11 belong also to the 50 genes top list characterizing $\mathrm{ST}$ as earlier shown in human [72], mice [73] and goat [74]. This list includes CALP AIN7 [75] and SNAI2 [76], involved in embryo attachment and implantation, and the disintegrins and metalloproteases ADAMTS1 and ADAM23 which encode key molecules for bovine endometrial remodelling [77]. In addition, a group of stromal genes including SERPING1 [78], C1R, C1S [79], SFRP1 and IGF1 are involved in immune modulation of embryo maternal interactions and response to IFNs.

Finally, among these first 50 genes that best separate ST from epithelial cells, numerous ones have not been described so far in the mammalian endometrium. For instance, we could not find any information on the expression and function in the endometrium of the following genes and their encoded proteins: MUSTN1, OSR2, TGM2, PCDH9, PGM5, MXRA5, MAMDC2, MRGPRF, RASD2, SULF1, RASL11A, ECM2, OLFML3 and P4HA3. These results may help to formulate new hypotheses for exploring new biological roles for genes of the stromal cells that are increasingly appearing as important cells in endometrial functions [80].

\section{Conclusion}

The present study provides novel and specific information about gene expression in ST, LE and GE endometrial cells from postpartum dairy cows and illustrates specific signatures of these cells at day- 15 of the estrous cycle. The most interesting result is that stromal cells express more genes than the two epithelial types and are associated with a greater number of pathways and ontology terms. The findings of this study will serve as a basis for in-depth investigations of cell type-specific molecular pathways and functions in bovine.

\section{Methods}

\section{Animals and experimental design}

This study was approved by the Uppsala Animal Experiment Ethics Board (application C329/12, PROLIFIC). After the study was conducted all cows have been kept in usual farm living conditions. Studies were conducted at the Swedish Livestock Research Centre in L vsta, Uppsala, Sweden. The animals were kept in a loose housing barn with a voluntary milking system (VMS, DeLaval, Tumba, Sweden), and had free access to drinking water. Second lactation cows of the Swedish Red breed (SRB; $n=12$ ) were fed two different diets i.e. i) high-energy diet (control, $n=6$ ) targeting $35 \mathrm{~kg}$ energycorrected milk (ECM) and ii) low-energy diet targeting $(\mathrm{n}=6) 25 \mathrm{~kg}$ energy-corrected milk (ECM). Details about diets and relationships between diet, metabolic profiles and negative energy balance (NEB) were previously reported [81]. In complement to the present study, the effects of NEB profiles on gene expression in the three endometrial cell types were analyzed and are described in the companion paper [17]. All cows initially recruited in the experiment have been checked for uterine health by using both clinical examination, including ultrasound examination and endometrial cytology. All cows included in further experiments (synchronization of estrus followed by uterine biopsies in view of LCM) had no clinical signs of uterine disease [82]. They presented less than $10 \%$ (four cows had percentages of immune cells between 7 and 10\%, and all other cows presented less than $5 \%$ of immune cells counted from a total of 400 cells) of immune cells from endometrial cytobrush at $42-45$ days post-partum, according to [83]. At day 60 after calving, estrous was synchronized using an intravaginal progesterone device (CIDR, Zoetis, Parsippany, NJ, USA) for a week followed by i.m. injection of $500 \mu \mathrm{g}$ of prostaglandin analog (Estrumate ${ }^{\circ}$, MSD animal health, Madison, NJ, USA) intramuscular as described [84]. Fifteen days after visual estrus detection, endometrial tissue biopsies were collected under epidural anesthesia with $0.5 \mathrm{mg} / \mathrm{kg}$ of $1 \%$ lidocaine hydrochloride (1\% Xylocaine ${ }^{\circ}$, Astra Zeneca, Cambridge, UK).

\section{Milk progesterone measurements and estrous cycle stage at time of biopsies}

Whole milk samples were collected by the automatic milking machine, VMS (DeLaval) three times per week from Day 7 to Day 120 after calving. Milk progesterone concentrations were measured with a commercial enzyme-linked immunosorbent assay (ELISA) (Ridge way 'M' kit, Ridgeway Science, Gloucester, UK) as previously published [81]. The progesterone concentration profile was used to determine the estrous cycle stage at the time of biopsy sampling.

\section{Collection of endometrial biopsies}

Endometrial biopsies were collected from the uterine horn ipsilateral to the corpus luteum by using Kevorkian-Younge uterine biopsy forceps (Alcyon, Paris, France). Biopsies were cut into 3 pieces (sizes $\approx 4 \times 4$ $\mathrm{mm}^{2}$ ). One of them was snap frozen in cold isopentane (2-Methylbutane, Sigma Aldrich, Saint Louis, MO, USA) previously placed in liquid nitrogen for $5 \mathrm{~min}$, and immediately embedded in $\approx 1 \mathrm{~cm}^{3}$ optimal cutting temperature (OCT) compound (VWR, Radnor, PA, USA). OCT conditioned biopsies were then put into dry ice and kept at $-80^{\circ} \mathrm{C}$ until sectioning. Tissue blocks 
were $8 \mu \mathrm{m}$ sectioned with a cryostat (Leica CM1860 Cryostat, Wetzlar, Germany) at $-20^{\circ} \mathrm{C}$ under RNA-free conditions. Tissue section slices were mounted on Super Frost slides RNA-free which were chilled on ice, following immersion in ice-cold 75\% RNA-free ethanol and stored at $-80^{\circ} \mathrm{C}$ until staining [85].

\section{Laser capture microdissection (LCM) and RNA isolation}

All procedures used were those previously published [85]. Tissue sections were mounted on RNAse-free glass slides which were chilled on ice, following immersion in cold $75 \%$ RNA-free ethanol at $-20^{\circ} \mathrm{C}$ in the cryostat and then transferred into $75 \%$ ethanol at RT (30 s), stained with $1 \%$ cresyl violet in ethanol $(15 \mathrm{~s})$, rinsed successively with $75 \%$ ethanol $(30 \mathrm{~s}), 95 \%$ ethanol $(2 \times 1$ $\mathrm{min}$ ), and $100 \%$ ethanol $(2 \times 1 \mathrm{~min})$ (anhydrous Ethanol absolute). Finally, the slides were completely dehydrated by immersion in pure xylene (M-xylene, Sigma-Aldrich, Saint-Quentin-Fallavier, France) for $2 \times 5 \mathrm{~min}$. Stained tissue sections were then immediately air dried. The LCM process was performed by using an ArcturusXT ${ }^{\mathrm{Tm}}$ Laser Capture Microdissection System and software (Applied Biosystems ${ }^{\circ}$ Arcturus, ThermoFisher Scietific, Waltham, MA, USA), within $1 \mathrm{~h}$ to avoid RNA degradation. Luminal epithelial cells (LE), glandular epithelial cells (GE) and stromal cells (ST) were harvested in sufficient numbers to obtain at least $10 \mathrm{ng}$ of total RNA for each endometrial cell type. Briefly, cells were captured from the slide onto LCM plastic caps (CapSure Macro LCM Caps, Arcturus) by using infrared laser with the following settings: power range 75 to $90 \mathrm{~mW}$, time 1300 to $3500 \mu \mathrm{sec}$ and $200 \mathrm{mV}$ intensity. Collected cells were then placed in a RNAse-free $0.5 \mathrm{~mL}$ microcentrifuge tube with $25 \mu \mathrm{L}$ extraction buffer (provided together with the PicoPure ${ }^{\mathrm{Tm}} \mathrm{RNA}$ isolation kit; KIT0202, Arcturus) and incubated for $30 \mathrm{~min}$ at $42{ }^{\circ} \mathrm{C}$. Captured cells in PicoPure extraction buffer were frozen at $-80^{\circ} \mathrm{C}$ before processing samples for RNA isolation. Total RNA from LCM samples was isolated and mRNA purified using the PicoPure ${ }^{\text {rm }}$ RNA isolation kit (KIT0202, Arcturus) following the manufacturer's protocol. RNA integrity value (RIN values) and quantity were evaluated using the Pico RNA chip on the Agilent 2100 Bioanalyzer (Agilent technologies, Santa Clara, CA, USA). Mean RNA integrity (RIN) values obtained from LCM samples and from the full tissue samples issued from the same biopsy were similar (paired T-test; Table S1).

\section{RNA sequencing and data analysis}

RNA sequencing libraries prepared from 24 samples were prepared and sequenced on GenomEast Platform (IGBMC, Cedex, France; http://genomeast.igbmc.fr/). Libraries were built using the Clontech SMART-Seq v4 Ultra Low Input RNA kit for Sequencing. Full length
cDNA were generated from 4 ng of total RNA using Clontech SMART-Seq v4 Ultra Low Input RNA kit for Sequencing (Takara Bio Europe, Ozyme, Montigny-LeBretonneux, France) according to manufacturer's instructions, with 10 cycles of PCR for cDNA amplification by Seq-Amp polymerase. Then, 600 pg of pre-amplified cDNA were then used as input for Tn 5 transposon tagmentation using the Nextera XT DNA Library Preparation Kit (Illumina, San Diego, CA) followed by 12 cycles of library amplification. Following purification with Agencourt AMPure XP beads (Beckman-Coulter, Roissy, France), the size and concentration of libraries were assessed by capillary electrophoresis. Sequencing was performed on an Illumina HiSeq 4000 with $50 \mathrm{bp}$ paired-end reads. Image analysis and base calling were performed using RTA 2.7.3 and bcl2fastq 2.17.1.14. Gene level exploratory analysis and differential expression were performed using the RNAseq workflow described by [86] and the update version http:// bioconductor.org/packages/release/bioc/vignettes/ DESeq2/inst/doc/DESeq2.html. html). The Salmon method [87] was used to quantify transcript abundance. The cDNA sequence database for Bos taurus was obtained from Ensembl (release-98; Bos_taurus.ARSUCD1.2.cdna.all.fa) and was used to build a reference index for the bovine transcriptome (see details in [87]. After quantifying RNA-seq data, tximport method [88] ( $\mathrm{R}$ package version 1.8.0) was used to import Salmon's transcript-level quantifications to the downstream DESeq2 package ( $R$ package, version 1.20.0) for analysis of differential expressed genes (DEGs) with the statistical method proposed [89]. The package DESeq2 provides methods to test for differential expression by use of negative binomial generalized linear models using the design formula ( cell-type) to compare gene expression between endometrial cell-types. Principal component analysis was performed with DESeq2 and with FactoMineR ( $R$ package, version 1.4.1) using the variance stabilizing transformation output files from DESeq2. Heatmap was generated in $\mathrm{R}$ software using the pheatmap package (version 1.0.12) and Venn diagrams were plotted with VennDiagram package (1.6.20). DEGs were identified in comparison between cell types with an adjusted $p$-value of 0.05 . The data have been deposited in NCBI's Gene Expression Omnibus and are accessible through GEO Series accession number GSE169638 (https://www.ncbi. nlm.nih.gov/geo/query/acc.cgi?acc=GSE169638).

\section{Gene ontology and KEGG pathway analysis}

Lists of genes expressed by the three types of endometrial cells were annotated into three categories of Gene Ontology (GO) pathways such as biological process (BP), cellular component (CC) and molecular function (MP) using PANTHER classification system (Protein Analysis 
THrough Evolutionary Relationships version 14.0, http:// pantherdb.org). PANTHER overrepresentation tests were performed using all genes from the whole Bos taurus genome or from specified list. Lists of GO terms were summarized and visualized in semantic space by REVIGO (http://revigo.irb.hr/) [90]. The SimRel semantic similarity score was used and the threshold was set at 0.15 .

\section{Statistical analysis}

The results of milk progesterone concentration are presented as LSmeans \pm S.E.M. Differences with associated $p$-value $<0.05$ were considered to be significant.

\begin{abstract}
Abbreviations
CIDR: Controlled Internal Drug Release; DAVID: Database for annotation, visualization and integrated discovery; DEG: Differentially expressed gene; Elisa: enzyme-linked immunosorbent assay; FDR: False discovery rate; GE:: Glandular epithelial cell; GO: Gene ontology; KEGG: Kyoto encyclopedia of genes and genomes; LCM: Laser capture microdissection; LE: Luminal epithelial cell; NorFor: Nordic Feed Evaluation System; OCT: Optimal cutting temperature coumpound; PANTHER: Protein analysis through evolutionary relationships; PCA: Principal Component Analysis; PGE2: Prostaglandin-E2; PGF2a: Prostaglandin-F2a; REVIGO:: Reduce, visualize gene ontology; RNA: Ribonucleic acid; RNA-Seq: RNA sequencing; SRB: Swedish Red breed; ST: Stromal cell; STRING: Search Tool for the Retrieval of Interacting Genes/ Proteins; TPM: Transcripts per million
\end{abstract}

\section{Supplementary Information}

The online version contains supplementary material available at https://doi. org/10.1186/s12864-021-07712-0.

Additional file 1: Figure S1. Milk progesterone concentrations $(\mathrm{ng} / \mathrm{ml})$ following estrus synchronization of cows $(n=12)$ with CIDR 60 days after calving. All the endometrial biopsies were taken at Day 14-15 following visual oestrus detection and were performed during the luteal phase of the cycle. Progesterone values are expressed as mean $+/-$ sem.

Additional file 2: Table S1. Number of samples of each cell type. RNA Integrity Number (RIN)] [mean value ( \pm s.e.m)] and average number of tissue sections required to obtain at least $10 \mathrm{ng}$ of total RNA in each endometrial cell type.

Additional file 3: Table S2. Expression of genes of key markers for immune cells in the three different endometrial cell types.

Additional file 4: Table S3. List of genes specifically expressed by the three endometrial cell types.

Additional file 5: Table S4. List of GO terms for under and over expressed genes three endometrial cell types.

Additional file 6: Table S5. List of genes expressed by endometrial cells according to the first two dimensions of the Principal Component Analysis.

\section{Acknowledgements}

We acknowledge Pierrette Reinaud (INRAE, Jouy en Josas, France) and Olivier Dubois for consulting during the LCM process and RNA analysis. The authors would like to thank the staff of Swedish Research Center, Lövsta, Uppsala, Sweden and Biology of Reproduction, Epigenetic, Environment and Development (BREED), INRA, Jouy en Josas, France for their help and support.

\section{Authors' contributions}

WC, PH, OS and GC contributed to the conception and design of the study. $S L, M R, C R, C B$ and TN contributed to sample collection and preparation. GC, $D P, Y G, W C, G A$ and $P H$ performed bioinformatics analysis and integration of data. WC performed the experiment, sample collection and preparation, data analyses and WC, GC, and PH drafted the manuscript. All authors provided critical feedback and helped shape research, analyses and manuscript. GC and $\mathrm{PH}$ are both senior co-authorship. We confirm that the final version of the manuscript has been read and approved by all named authors. We further confirm that the order of authors listed in the manuscript has been approved by all of us.

\section{Funding}

This work was funded by from European Union [FP7-KBBE-2012-6, Prolific (Pluridisciplinary study for a RObust and sustainabLe Improvement of the Fertility In Cows), Grant agreement number 311776 for animals, reagents, sequencing and travel. WC was supported by the Rajamangala University of Technology Srivijaya (RMUTSV), Thailand. The funders had no role in study design, data collection, and interpretation, or the decision to submit the work for publication.

\section{Availability of data and materials}

The data discussed in this publication have been deposited in NCBI's Gene Expression Omnibus [91] and are accessible through GEO Series accession number GSE169638 (https://www.ncbi.nlm.nih.gov/geo/query/acc.cgi?acc= GSE169638). The gene accession numbers indicated in the additional files refer to the corresponding Ensembl identifier (https://www.ensembl.org/Bos taurus/)(Bos taurus:ARS-UCD1.2). Gene names were retrieved using the Ensembl BioMart tool.

\section{Declarations}

Ethics approval and consent to participate

All experimental protocols were approved by the Uppsala Animal Experiment Ethics Board (application C329/12, PROLIFIC)(Uppsala University, Sweden) and were carried out in accordance with the terms of the Swedish Animal Welfare Act. After the study was completed, all cows were kept alive under normal husbandry conditions.

\section{Consent for publication}

Not applicable.

\section{Competing interests}

The authors declare that they have no competing interests.

\section{Author details}

${ }^{1}$ Department of Clinical Sciences, Swedish University of Agricultural Sciences, SLU, PO Box 7054, 75007 Uppsala, Sweden. 'Faculty of Veterinary Science, Rajamangala University of Technolgy Srivijaya (RUTS), Thungyai, Nakhon si thammarat 80240, Thailand. ${ }^{3}$ Université Paris-Saclay, UVSQ, INRAE, BREED, 78350 Jouy-en-Josas, France. ${ }^{4}$ GenomEast Platform CERBM GIE, IGBMC, 67404 Illkirch, Cedex, France. ${ }^{5}$ Université Paris-Saclay, INRAE, AgroParisTech, GABI, 78350 Jouy en Josas, France. ${ }^{6}$ Department of Animal Breeding and Genetics, Molecular Genetics, Swedish University of Agricultural Sciences, SLU, PO Box 7023, 75007 Uppsala, Sweden.

Received: 17 June 2020 Accepted: 11 April 2021

Published online: 18 June 2021

\section{References}

1. Guillomot M, Guay P. Ultrastructural features of the cell surfaces of uterine and trophoblastic epithelia during embryo attachment in the cow. Anat Rec. 1982;204(4):315-22. https://doi.org/10.1002/ar.1092040404.

2. Spencer TE, Johnson GA, Burghardt RC, Bazer FW. Progesterone and placental hormone actions on the uterus: insights from domestic animals. Biol Reprod. 2004;71(1):2-10. https://doi.org/10.1095/biolreprod.103.024133.

3. Bauersachs S, Ulbrich SE, Gross K, Schmidt SE, Meyer HH, Einspanier R, et al. Gene expression profiling of bovine endometrium during the oestrous cycle: detection of molecular pathways involved in functional changes. J Mol Endocrinol. 2005;34(3):889-908. https://doi.org/10.1677/jme.1.01799.

4. Mitko K, Ulbrich SE, Wenigerkind H, Sinowatz F, Blum H, Wolf E, et al. Dynamic changes in messenger RNA profiles of bovine endometrium during the oestrous cycle. Reproduction. 2008;135(2):225-40. https://doi. org/10.1530/REP-07-0415.

5. Forde N, Carter F, Fair T, Crowe MA, Evans AC, Spencer TE, et al. Progesterone-regulated changes in endometrial gene expression contribute 
to advanced conceptus development in cattle. Biol Reprod. 2009;81(4):78494. https://doi.org/10.1095/biolreprod.108.074336.

6. Forde N, Carter F, Spencer TE, Bazer FW, Sandra O, Mansouri-Attia N, et al. Conceptus-induced changes in the endometrial transcriptome: how soon does the cow know she is pregnant? Biol Reprod. 2011;85(1):144-56. https://doi.org/10.1095/biolreprod.110.090019.

7. Passaro C, Tutt D, Bages-Arnal S, Maicas C, Laguna-Barraza R, Gutierrez-Adan A, et al. Global transcriptomic response of bovine endometrium to blastocyst-stage embryos. Reproduction. 2019;158(3):223-35. https://doi. org/10.1530/REP-19-0064.

8. Mathew DJ, Sanchez JM, Passaro C, Charpigny G, Behura SK, Spencer TE, et al. Interferon tau-dependent and independent effects of the bovine conceptus on the endometrial transcriptomedagger. Biol Reprod. 2019; 100(2):365-80. https://doi.org/10.1093/biolre/ioy199.

9. Minten MA, Bilby TR, Bruno RG, Allen CC, Madsen CA, Wang Z, et al. Effects of fertility on gene expression and function of the bovine endometrium. PLoS One. 2013;8(8):e69444. https://doi.org/10.1371/journal.pone.0069444.

10. Geary TW, Burns GW, Moraes JG, Moss JI, Denicol AC, Dobbs KB, et al. Identification of beef heifers with superior uterine capacity for pregnancy. Biol Reprod. 2016;95(2):47. https://doi.org/10.1095/biolreprod.116.141390.

11. Sanchez JM, Passaro C, Forde N, Browne JA, Behura SK, Fernandez-Fuertes B, et al. Do differences in the endometrial transcriptome between uterine horns ipsilateral and contralateral to the corpus luteum influence conceptus growth to day 14 in cattle? Biol Reprod. 2019;100(1):86-100. https://doi. org/10.1093/biolre/ioy185.

12. Mansouri-Attia N, Aubert J, Reinaud P, Giraud-Delville C, Taghouti G, Galio L, et al. Gene expression profiles of bovine caruncular and intercaruncular endometrium at implantation. Physiol Genomics. 2009;39(1):14-27. https:// doi.org/10.1152/physiolgenomics.90404.2008.

13. Niklaus AL, Pollard JW. Mining the mouse transcriptome of receptive endometrium reveals distinct molecular signatures for the luminal and glandular epithelium. Endocrinology. 2006;147(7):3375-90. https://doi.org/1 0.1210/en.2005-1665.

14. Brooks K, Burns GW, Moraes JG, Spencer TE. Analysis of the uterine epithelial and conceptus transcriptome and luminal fluid proteome during the Periimplantation period of pregnancy in sheep. Biol Reprod. 2016;95(4):88. https://doi.org/10.1095/biolreprod.116.141945.

15. Zeng S, Bick J, Ulbrich SE, Bauersachs S. Cell type-specific analysis of transcriptome changes in the porcine endometrium on day 12 of pregnancy. BMC Genomics. 2018;19(1):459. https://doi.org/10.1186/s12864-018-4855-y.

16. Wathes DC, Cheng ZR, Chowdhury W, Fenwick MA, Fitzpatrick R, Morris DG, et al. Negative energy balance alters global gene expression and immune responses in the uterus of postpartum dairy cows. Physiol Genomics. 2009; 39(1):1-13. https://doi.org/10.1152/physiolgenomics.00064.2009.

17. Chankeaw W, Lignier S, Richard C, Ntallaris T, Raliou M, G. Y, Plassard D, Bevilacqua C, Sandra O, Andersson G et al. Analysis of the transcriptome of bovine endometrial cells isolated by laser micro-dissection (2): specific impacts of post-partum negative energy balance on stromal, glandular and luminal epithelial cells. BMC Genomics. 2021. https://doi.org/10.1186/s12 864-021-07713-z.

18. Wagner GP, Kin K, Lynch VJ. Measurement of mRNA abundance using RNAseq data: RPKM measure is inconsistent among samples. Theory Biosci. 2012;131(4):281-5. https://doi.org/10.1007/s12064-012-0162-3.

19. Yanaihara A, Otsuka Y, Iwasaki S, Koide K, Aida T, Okai T. Comparison in gene expression of secretory human endometrium using laser microdissection. Reprod Biol Endocrinol. 2004;2(1):66. https://doi.org/10.1 186/1477-7827-2-66.

20. Scaravaggi I, Borel N, Romer R, Imboden I, Ulbrich SE, Zeng S, et al. Cell type-specific endometrial transcriptome changes during initial recognition of pregnancy in the mare. Reprod Fertil Dev. 2019;31(3):496-508. https://doi. org/10.1071/RD18144.

21. Cerri RL, Thompson IM, Kim IH, Ealy AD, Hansen PJ, Staples CR, et al. Effects of lactation and pregnancy on gene expression of endometrium of Holstein cows at day 17 of the estrous cycle or pregnancy. J Dairy Sci. 2012;95(10): 5657-75. https://doi.org/10.3168/jds.2011-5114.

22. Uhlen M, Fagerberg L, Hallstrom BM, Lindskog C, Oksvold P, Mardinoglu A, et al. Proteomics. Tissue-based map of the human proteome. Science. 2015; 347(6220):1260419.

23. Lara E, Rivera N, Cabezas J, Navarrete F, Saravia F, Rodriquez-Alvarez L, Castro FO: Endometrial Stem Cells in Farm Animals: Potential Role in Uterine Physiology and Pathology. Bioengineering (Basel). 2018:5(3):75. https://doi.org/10.3390/bioengineering50300753.
24. Satterfield MC, Dunlap KA, Hayashi K, Burghardt RC, Spencer TE, Bazer FW. Tight and adherens junctions in the ovine uterus: differential regulation by pregnancy and progesterone. Endocrinology. 2007;148(8):3922-31. https:// doi.org/10.1210/en.2007-0321.

25. Reardon SN, King ML, MacLean JA 2nd, Mann JL, DeMayo FJ, Lydon JP, et al. $\mathrm{CDH} 1$ is essential for endometrial differentiation, gland development, and adult function in the mouse uterus. Biol Reprod. 2012;86(5):141 141110.

26. Wendeler MW, Jung R, Himmelbauer H, Gessner R. Unique gene structure and paralogy define the 7D-cadherin family. Cell Mol Life Sci. 2006;63(13): 1564-73. https://doi.org/10.1007/s00018-006-6014-x.

27. Alimperti $S$, Andreadis ST. CDH2 and $\mathrm{CDH} 11$ act as regulators of stem cell fate decisions. Stem Cell Res. 2015;14(3):270-82. https://doi.org/10.1016/j. scr.2015.02.002.

28. Andreeva AV, Kutuzov MA. Cadherin 13 in cancer. Genes Chromosomes Cancer. 2010;49(9):775-90. https://doi.org/10.1002/gcc.20787.

29. Hata M, Yamanegi K, Yamada N, Ohyama H, Yukitatsu Y, Nakasho K, et al. Estrogen decreases the expression of claudin-5 in vascular endothelial cells in the murine uterus. Endocr J. 2014;61 (7):705-15. https://doi.org/10.1507/ endocrj.EJ13-0442.

30. Bellessort B, Bachelot A, Grouthier V, De Lombares C, Narboux-Neme N, Garagnani $\mathrm{P}$, et al. Comparative analysis of molecular signatures suggests the use of gabapentin for the management of endometriosis-associated pain. J Pain Res. 2018;11:715-25. https://doi.org/10.2147/JPR.S163611.

31. Luk IY, Reehorst CM, Mariadason JM: ELF3, ELF5, EHF and SPDEF Transcription Factors in Tissue Homeostasis and Cancer. Molecules. 2018; 23(9):2191. https://doi.org/10.3390/molecules23092191.

32. Gao H, Wu G, Spencer TE, Johnson GA, Bazer FW. Select nutrients in the ovine uterine lumen. III. Cationic amino acid transporters in the ovine uterus and peri-implantation conceptuses. Biol Reprod. 2009;80(3):602-9. https:// doi.org/10.1095/biolreprod.108.073890.

33. Gao H, Wu G, Spencer TE, Johnson GA, Bazer FW. Select nutrients in the ovine uterine lumen. IV. Expression of neutral and acidic amino acid transporters in ovine uteri and peri-implantation conceptuses. Biol Reprod. 2009;80(6):1196-208. https://doi.org/10.1095/biolreprod.108.075440.

34. Gao H, Wu G, Spencer TE, Johnson GA, Bazer FW. Select nutrients in the ovine uterine lumen. li. Glucose transporters in the uterus and periimplantation conceptuses. Biol Reprod. 2009;80(1):94-104. https://doi.org/1 0.1095/biolreprod.108.071654.

35. Forde N, Spencer TE, Bazer FW, Song G, Roche JF, Lonergan P. Effect of pregnancy and progesterone concentration on expression of genes encoding for transporters or secreted proteins in the bovine endometrium. Physiol Genomics. 2010;41(1):53-62. https://doi.org/10.1152/ physiolgenomics.00162.2009.

36. Liu Y, Wang DK, Chen LM. The physiology of bicarbonate transporters in mammalian reproduction. Biol Reprod. 2012;86(4):99. https://doi.org/10.1 095/biolreprod.111.096826.

37. Satir $P$, Christensen ST. Overview of structure and function of mammalian cilia. Annu Rev Physiol. 2007;69(1):377-400. https://doi.org/10.1146/annurev. physiol.69.040705.141236.

38. Roberts AJ, Kon T, Knight PJ, Sutoh K, Burgess SA. Functions and mechanics of dynein motor proteins. Nat Rev Mol Cell Biol. 2013;14(11):713-26. https:// doi.org/10.1038/nrm3667.

39. Schatz G, Schneiter M, Ricka J, Kuhni-Boghenbor K, Tschanz SA, Doherr MG, et al. Ciliary beating plane and wave propagation in the bovine oviduct. Cells Tissues Organs. 2013;198(6):457-69. https://doi.org/10.1159/000360155.

40. Kojima Y, Selander U. Cyclical changes in the fine structure of bovine endometrial gland cells. Z Zellforsch Mikrosk Anat. 1970;104(1):69-86. https://doi.org/10.1007/BF00340050.

41. Hoyes A. The endometrial glands of the pregnant sheep: an ultrastructural study. J Anat. 1972;111(1):55-67.

42. Filant J, Zhou H, Spencer TE. Progesterone inhibits uterine gland development in the neonatal mouse uterus. Biol Reprod. 2012;86(5):146 141-149.

43. Padua MB, Hansen PJ. Evolution and function of the uterine serpins (SERP INA14). Am J Reprod Immunol. 2010;64(4):265-74. https://doi.org/10.1111/j.1 600-0897.2010.00901.x.

44. Song G, Spencer TE, Bazer FW. Cathepsins in the ovine uterus: regulation by pregnancy, progesterone, and interferon tau. Endocrinology. 2005;146(11): 4825-33. https://doi.org/10.1210/en.2005-0768.

45. Ulbrich SE, Frohlich T, Schulke K, Englberger E, Waldschmitt N, Arnold GJ, et al. Evidence for estrogen-dependent uterine serpin (SERPINA14) 
expression during estrus in the bovine endometrial glandular epithelium and lumen. Biol Reprod. 2009;81(4):795-805. https://doi.org/10.1095/ biolreprod.108.075184.

46. Lee RK, Fan CC, Hwu YM, Lu CH, Lin MH, Chen YJ, et al. SERPINE2, an inhibitor of plasminogen activators, is highly expressed in the human endometrium during the secretory phase. Reprod Biol Endocrinol. 2011;9(1): 38. https://doi.org/10.1186/1477-7827-9-38.

47. Wathes DC, Cheng Z, Fenwick MA, Fitzpatrick R, Patton J. Influence of energy balance on the somatotrophic axis and matrix metalloproteinase expression in the endometrium of the postpartum dairy cow. Reproduction. 2011;141(2):269-81. https://doi.org/10.1530/REP-10-0177.

48. Geisert RD, Lee CY, Simmen FA, Zavy MT, Fliss AE, Bazer FW, et al. Expression of messenger RNAs encoding insulin-like growth factor-I, - II, and insulin-like growth factor binding protein-2 in bovine endometrium during the estrous cycle and early pregnancy. Biol Reprod. 1991;45(6):975-83. https://doi.org/10.1095/biolreprod45.6.975.

49. McCarthy SD, Roche JF, Forde N. Temporal changes in endometrial gene expression and protein localization of members of the IGF family in cattle: effects of progesterone and pregnancy. Physiol Genomics. 2012:44(2):13040. https://doi.org/10.1152/physiolgenomics.00106.2011.

50. Simmons RM, Erikson DW, Kim J, Burghardt RC, Bazer FW, Johnson GA, et al. Insulin-like growth factor binding protein-1 in the ruminant uterus: potential endometrial marker and regulator of conceptus elongation. Endocrinology. 2009;150(9):4295-305. https://doi.org/10.1210/en.2009-0060.

51. Robinson RS, Mann GE, Gadd TS, Lamming GE, Wathes DC. The expression of the IGF system in the bovine uterus throughout the oestrous cycle and early pregnancy. J Endocrinol. 2000;165(2):231-43. https://doi.org/10.1677/ joe.0.1650231.

52. Davoodi S, Cooke RF, Fernandes AC, Cappellozza BI, Vasconcelos JL, Cerri RL. Expression of estrus modifies the gene expression profile in reproductive tissues on day 19 of gestation in beef cows. Theriogenology. 2016;85(4):645-55. https://doi.org/10.1016/j.theriogenology.2015.10.002.

53. Tayade C, Esadeg S, Fang Y, Croy BA. Functions of alpha 2 macroglobulins in pregnancy. Mol Cell Endocrinol. 2005;245(1-2):60-6. https://doi.org/10.1 016/j.mce.2005.10.004.

54. Geisert R, Ashworth M, Malayer J. Expression of inter--trypsin inhibitor heavy chains in endometrium of cyclic and pregnant gilts. Reproduction. 2003; 126(5):621-7. https://doi.org/10.1530/rep.0.1260621.

55. O'Connell AR, McNatty KP, Hurst PR, Spencer TE, Bazer FW, Reader KL, et al. Activin a and follistatin during the oestrous cycle and early pregnancy in ewes. J Endocrinol. 2016;228(3):193-203. https://doi.org/10.1530/JOE-15-03 67.

56. Boruszewska D, Kowalczyk-Zieba I, Piotrowska-Tomala K, Saulnier-Blache JS, Acosta T, Skarzynski DJ, et al. Which bovine endometrial cells are the source of and target for lysophosphatidic acid? Reprod Biol. 2013;13(1):100-3. https://doi.org/10.1016/j.repbio.2013.01.166.

57. Liszewska E, Reinaud P, Billon-Denis E, Dubois O, Robin P, Charpigny G. Lysophosphatidic acid signaling during embryo development in sheep: involvement in prostaglandin synthesis. Endocrinology. 2009;150(1):422-34. https://doi.org/10.1210/en.2008-0749.

58. Liszewska E, Reinaud P, Dubois O, Charpigny G. Lysophosphatidic acid receptors in ovine uterus during estrous cycle and early pregnancy and their regulation by progesterone. Domest Anim Endocrinol. 2012;42(1):3142. https://doi.org/10.1016/j.domaniend.2011.08.003.

59. Robinson RS, Mann GE, Lamming GE, Wathes DC. The effect of pregnancy on the expression of uterine oxytocin, oestrogen and progesterone receptors during early pregnancy in the cow. J Endocrinol. 1999;160(1):2133. https://doi.org/10.1677/joe.0.1600021.

60. Scolari SC, Pugliesi G, Strefezzi RF, Andrade SC, Coutinho LL, Binelli M. Dynamic remodeling of endometrial extracellular matrix regulates embryo receptivity in cattle. Reproduction. 2016

61. Hein S, Yamamoto SY, Okazaki K, Jourdan-LeSaux C, Csiszar K, BryantGreenwood GD. Lysyl oxidases: expression in the fetal membranes and placenta. Placenta. 2001;22(1):49-57. https://doi.org/10.1053/plac.2000.0580

62. Liu C, Tong H, Li S, Yan Y. Effect of ECM2 expression on bovine skeletal muscle-derived satellite cell differentiation. Cell Biol Int. 2018;42(5):525-32. https://doi.org/10.1002/cbin.10927.

63. Gibbs GM, Roelants K, O'Bryan MK. The CAP superfamily: cysteine-rich secretory proteins, antigen 5, and pathogenesis-related 1 proteins--roles in reproduction, cancer, and immune defense. Endocr Rev. 2008;29(7):865-97. https://doi.org/10.1210/er.2008-0032.
64. Gurates B, Sebastian S, Yang S, Zhou J, Tamura M, Fang Z, et al. WT1 and DAX-1 inhibit aromatase P450 expression in human endometrial and endometriotic stromal cells. J Clin Endocrinol Metab. 2002;87(9):4369-77. https://doi.org/10.1210/jc.2002-020522.

65. Hayashi K, Spencer TE. WNT pathways in the neonatal ovine uterus: potential specification of endometrial gland morphogenesis by SFRP2. Biol Reprod. 2006;74(4):721-33. https://doi.org/10.1095/biolreprod.105.049718.

66. Gargett CE, Schwab KE, Zillwood RM, Nguyen HP, Wu D. Isolation and culture of epithelial progenitors and mesenchymal stem cells from human endometrium. Biol Reprod. 2009;80(6):1136-45. https://doi.org/10.1095/ biolreprod.108.075226.

67. Yu J, Berga SL, Zou W, Sun HY, Johnston-MacAnanny E, Yalcinkaya T, et al. Gap junction blockade induces apoptosis in human endometrial stromal cells. Mol Reprod Dev. 2014;81(7):666-75. https://doi.org/10.1002/mrd.22334.

68. Yotova I, Hsu E, Do C, Gaba A, Sczabolcs M, Dekan S, et al. Epigenetic alterations affecting transcription factors and signaling pathways in stromal cells of endometriosis. PLoS One. 2017;12(1):e0170859. https://doi.org/10.13 71/journal.pone.0170859.

69. Rodriguez-Alonso B, Hamdi M, Sanchez JM, Maillo V, Gutierrez-Adan A, Lonergan $\mathrm{P}$, et al. An approach to study the local embryo effect on gene expression in the bovine oviduct epithelium in vivo. Reprod Domest Anim. 2019;54(12):1516-23. https://doi.org/10.1111/rda.13558.

70. Lim W, Bae H, Bazer FW, Song G. Brain-derived neurotrophic factor improves proliferation of endometrial epithelial cells by inhibition of endoplasmic reticulum stress during early pregnancy. J Cell Physiol. 2017; 232(12):3641-51. https://doi.org/10.1002/jcp.25834.

71. Wessels JM, Wu L, Leyland NA, Wang H, Foster WG. The brain-uterus connection: brain derived neurotrophic factor (BDNF) and its receptor (Ntrk2) are conserved in the mammalian uterus. PLoS One. 2014;9(4):e94036. https://doi.org/10.1371/journal.pone.0094036.

72. Xu B, Geerts D, Bu Z, Ai J, Jin L, Li Y, et al. Regulation of endometrial receptivity by the highly expressed HOXA9, HOXA11 and HOXD10 HOXclass homeobox genes. Hum Reprod. 2014;29(4):781-90. https://doi.org/10.1 093/humrep/deu004.

73. Daftary GS, Taylor HS. Implantation in the human: the role of HOX genes. Semin Reprod Med. 2000;18(3):311-20. https://doi.org/10.1055/s-2000-12568.

74. Zhang Y, Zhang L, Yu C, Du X, Liu X, Liu J, et al. Effects of interferon tau on endometrial epithelial cells in caprine in vitro. Gene Expr Patterns. 2017;2526:142-8. https://doi.org/10.1016/j.gep.2017.06.010.

75. Yan Q, Huang C, Jiang Y, Shan H, Jiang R, Wang J, et al. Calpain7 impairs embryo implantation by downregulating beta3-integrin expression via degradation of HOXA10. Cell Death Dis. 2018;9(3):291. https://doi.org/10.103 8/s41419-018-0317-3.

76. Du F, Yang R, Ma HL, Wang QY, Wei SL. Expression of transcriptional repressor slug gene in mouse endometrium and its effect during embryo implantation. Appl Biochem Biotechnol. 2009;157(2):346-55. https://doi. org/10.1007/s12010-008-8521-8.

77. Mishra B, Koshi K, Kizaki K, Ushizawa K, Takahashi T, Hosoe M, et al. Expression of ADAMTS1 mRNA in bovine endometrium and placenta during gestation. Domest Anim Endocrinol. 2013;45(1):43-8. https://doi. org/10.1016/j.domaniend.2013.04.002.

78. Genis S, Aris A, Kaur M, Cerri RLA. Effect of metritis on endometrium tissue transcriptome during puerperium in Holstein lactating cows. Theriogenology. 2018;122:116-23. https:/doi.org/10.1016/j.theriogenology.2018.09.004.

79. Bauersachs S, Mitko K, Ulbrich SE, Blum H, Wolf E. Transcriptome studies of bovine endometrium reveal molecular profiles characteristic for specific stages of estrous cycle and early pregnancy. Exp Clin Endocrinol Diabetes. 2008;116(7):371-84. https://doi.org/10.1055/s-2008-1076714.

80. Queckborner S, Syk Lundberg E, Gemzell-Danielsson K, Davies LC. Endometrial stromal cells exhibit a distinct phenotypic and immunomodulatory profile. Stem Cell Res Ther. 2020;11(1):15. https://doi. org/10.1186/s13287-019-1496-2.

81. Ntallaris T, Humblot $P$, Bage R, Sjunnesson $Y$, Dupont J, Berglund B. Effect of energy balance profiles on metabolic and reproductive response in Holstein and Swedish red cows. Theriogenology. 2017;90:276-83. https://doi.org/10.1 016/j.theriogenology.2016.12.012.

82. Sheldon IM, Lewis GS, LeBlanc S, Gilbert RO. Defining postpartum uterine disease in cattle. Theriogenology. 2006;65(8):1516-30. https://doi.org/10.101 6/j.theriogenology.2005.08.021.

83. Kasimanickam R, Duffield TF, Foster RA, Gartley CJ, Leslie KE, Walton JS, et al. Endometrial cytology and ultrasonography for the detection of subclinical 
endometritis in postpartum dairy cows. Theriogenology. 2004;62(1-2):9-23. https://doi.org/10.1016/.jtheriogenology.2003.03.001.

84. Johnson S, Funston R, Hall J, Lamb G, Lauderdale J, Patterson D, Perry G:

Protocols for synchronization of estrus and ovulation. Proceedings Applied Reproductive Strategies in Beef Cattle San Antonio, TX 2010.

85. Bevilacqua C, Makhzami S, Helbling J-C, Defrenaix P, Martin P. Maintaining RNA integrity in a homogeneous population of mammary epithelial cells isolated by laser capture microdissection. BMC Cell Biol. 2010;11(1):95. https://doi.org/10.1186/1471-2121-11-95.

86. Love Ml, Anders S, Kim V, Huber W. RNA-Seq workflow: gene-level exploratory analysis and differential expression. F1000Res. 2015:4:1070

87. Patro R, Duggal G, Love MI, Irizarry RA, Kingsford C. Salmon provides fast and bias-aware quantification of transcript expression. Nat Methods. 2017; 14(4):417-9. https://doi.org/10.1038/nmeth.4197.

88. Soneson C, Love Ml, Robinson MD. Differential analyses for RNA-seq: transcript-level estimates improve gene-level inferences. F1000Res. 2015;4: 1521.

89. Love Ml, Huber W, Anders S. Moderated estimation of fold change and dispersion for RNA-seq data with DESeq2. Genome Biol. 2014;15(12):550. https://doi.org/10.1186/s13059-014-0550-8.

90. Supek F, Bosnjak M, Skunca N, Smuc T. REVIGO summarizes and visualizes long lists of gene ontology terms. PLoS One. 2011;6(7):e21800. https://doi. org/10.1371/journal.pone.0021800.

91. Edgar R, Domrachev M, Lash AE. Gene expression omnibus: NCBI gene expression and hybridization array data repository. Nucleic Acids Res. 2002; 30(1):207-10. https://doi.org/10.1093/nar/30.1.207.

\section{Publisher's Note}

Springer Nature remains neutral with regard to jurisdictional claims in published maps and institutional affiliations.

Ready to submit your research? Choose BMC and benefit from:

- fast, convenient online submission

- thorough peer review by experienced researchers in your field

- rapid publication on acceptance

- support for research data, including large and complex data types

- gold Open Access which fosters wider collaboration and increased citations

- maximum visibility for your research: over $100 \mathrm{M}$ website views per year

At BMC, research is always in progress.

Learn more biomedcentral.com/submissions 